$\underline{\text { www.degruyter.com/view/j/arls }}$

\title{
Rapid and Simple Method for the Extraction of Genomic DNA from Tobacco (Nicotiana tabacum L.) Seedlings
}

\author{
Javier Martinez \\ Tobacco Research Institute, Department of Genetics and Phytopathology, Carretera Tumbadero km 8 1/2, \\ San Antonio de los Baños, Artemisa, Cuba
}

Accepted June, 2017

\begin{abstract}
Tobacco (Nicotiana tabacum L.) plants are known to present high levels of secondary metabolites that increase with the plant age. Molecular biology techniques like restriction enzyme digestion and PCR, requires as pre-requisite the isolation of genomic DNA of suitable purity, good quality and with low levels of contaminants. Several methods to isolate pure and intact tobacco DNA for molecular research purposes have been developed. In this work, a combination between a tobacco seed germination technique using gibberellic acid and a fast and simple genomic DNA extraction method from 14-days old tobacco seedlings to reduce the secondary metabolites levels in the final samples was presented. Ten tobacco genotypes were used to evaluate this method. The DNA concentrations were in a range between $0.73 \mu \mathrm{g} / \mu \mathrm{L}$ to 1.47 $\mu \mathrm{g} / \mu \mathrm{L}$ for Habana-2000 cv. and Criollo cv., respectively. The absorbance ratios values to determine DNA quality were acceptable. This method allows the obtaining of high molecular weight DNA suitable for digestion with restriction enzymes, EcoRI and BamHI. Tobacco seedlings DNA in a short period of time, in a simple way and with a low cost, was obtained with this extraction method.
\end{abstract}

Keywords: tobacco, seedlings, genomic DNA, enzymatic digestion.

\section{Introduction}

The genomic DNA extraction from tobacco (Nicotiana tabacum L.) adult plants, sometimes results in a long and laborious process. It has been found that DNA extracts from plant tissues which have already passed the bud formation stage are problematic and unstable under storage conditions for long periods of time [1]. The final DNA quality and concentration obtained varies and depends on the starting material (Dark, Burley, Flue-cured, Oriental, etc. tobacco), on the presence of secondary metabolites such as polyphenols, polysaccharides, tannins and

\section{* Corresponding author: Javier Martinez, imartinez.iit@gmail.com}

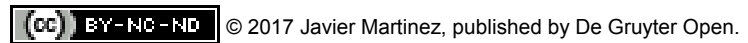
This work was licensed under the Creative Commons Attribution-NonCommercialNoDerivs 3.0 License terpenoids, as well as the extraction protocol itself.

To reduce the presence of contaminants, the extraction is made from young tissues that have low concentrations of secondary metabolites $[2,3$, 4]. These may undergo rapid oxidation during tissue rupture, irreversibly bind to DNA and coprecipitate during the process, and then prevent their use in PCR, restriction enzyme digestion or sequencing, due to inhibition of polymerases or endonucleases $[4,5,6]$.

Numerous protocols have been established to isolate pure and intact DNA from plants, but many of these consume considerable time, large amounts of plant tissue and only allow a few samples to be processed. On the other hand, various commercial kits are available to extract genomic DNA from plants with sufficient quality, but sometimes the yield is low. In addition, the 
cost is particularly expensive when it is required to analyze a high number of samples [7, 8, 9].

The objective of this work was to present the combination of tobacco seed germination promoted by gibberellic acid with a simple, fast and reliable method for extracting genomic DNA from 14-day old tobacco seedlings.

\section{Material and Methods}

Plant material

Fifty seeds of each 10 tobacco cultivars (Table 1) were placed inside a Petri dish containing a qualitative filter paper (Whatman, UK) moistened with $0.015 \%$ gibberellic acid solution (GA3) (Sigma-Aldrich, USA). Plates were coated to create a moist chamber and incubated at $22^{\circ} \mathrm{C}$ at a rate of 16 hours light / 8 hours darkness, for two weeks. The 14-day-old seedlings ( about 10-15 plantlets with mean height $1.0 \pm 0.2 \mathrm{~cm}$ ) were harvested for extraction of genomic DNA. (Fig. 1).

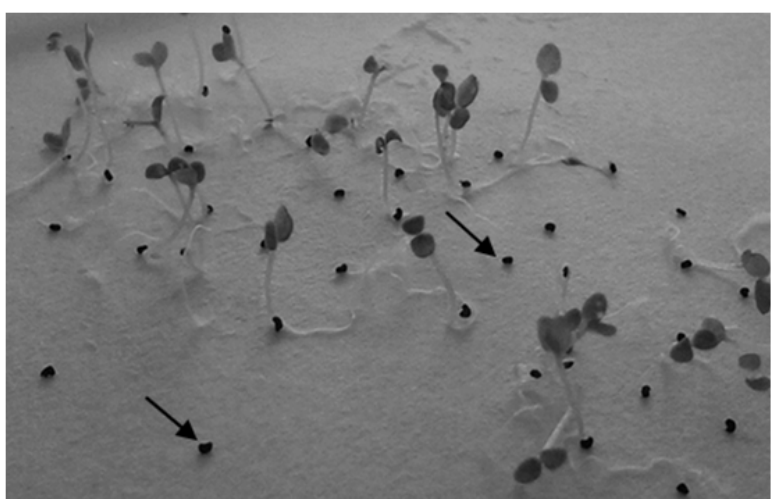

Fig. 1. The 14-day tobacco seedlings from which genomic DNA extraction was performed. It is important to remove the seed remains (black arrows) to avoid contamination.

\section{Reagents and Solutions}

- Extraction Buffer (EB): 200mM Tris- $\mathrm{HCl}$, $\mathrm{pH}$ 8; $150 \mathrm{mM} \mathrm{NaCl} ; 25 \mathrm{mM}$ EDTA; $0.5 \%$ SDS (modified from [10])

- $\quad P: C: I$ Solution : Phenol (equilibrated with 10mM Tris- $\mathrm{HCl}, \mathrm{pH}$ 8; $1 \mathrm{mM}$ EDTA): Chloroform: Isoamilic Alcohol $(25: 24: 1)(v / v / v)$

- Chilled Isopropanol $\left(-30^{\circ} \mathrm{C}\right)$

- Ethanol 70\%

- TE Buffer: 10mM Tris-HCl $\mathrm{pH} 8 ; 1 \mathrm{mM}$ EDTA pH 8.

DNA extraction method

- Place in a $1.5 \mathrm{~mL}$ vial, about $30 \mathrm{mg}$ of seedlings with $200 \mu \mathrm{l}$ EB. Incubate at RT for 5 minutes

- Homogenize manually with an Eppendorf homogenizer until no visible pieces remain. The solution turns greenish.

- Invert the vial 3-4 times and vortex.
- $\quad$ Add $500 \mu \mathrm{L}$ of P: C: I Solution and vortex.

- Centrifuge at $13000 \mathrm{rpm} / 1$ minute. Collect the upper aqueous phase, discard the rest.

- Add a same volume of chilled isopropanol. Invert 3-4 times and incubate 30 minutes $/-30^{\circ} \mathrm{C}$.

- Centrifuge at $10000 \mathrm{rpm} / 5$ minutes. Discard supernatant.

- Wash the pellet with $500 \mu \mathrm{L}$ of Ethanol $70 \%$. Centrifuge at $13000 \mathrm{rpm} / 1$ minute.

- Eliminate the ethanol by inverting the tube. Give a centrifuge spin, eliminate remain ethanol at the bottom with a 20 $200 \mu \mathrm{L}$ micropipette or similar.

- Leave to dry in a thermostat bath or thermal block at $65^{\circ} \mathrm{C}$ for 10 minutes, until the smell of ethanol disappears.

- Resuspend the DNA with $50 \mu \mathrm{L}$ of TE Buffer, sterile or bidestilated water.

- Storage at $4^{0} \mathrm{C}$ for immediate use o at $30^{\circ} \mathrm{C}$ for later use.

DNA Quantification

The absorbance of the samples at $260 \mathrm{~nm}, 280 \mathrm{~nm}$ and 320nm [11] was determined on a UV / Visible Spectrophotometer (Thermo Scientific, USA) and the DNA concentration was calculated by the formula:

ADN $(\mu \mathrm{g} / \mu \mathrm{L})=\left(\mathrm{Abs}_{260 \mathrm{~nm}}-\mathrm{Abs}_{320 \mathrm{~nm}}\right)^{*}$ dilution factor*50*0.001

Evaluation of DNA quality

The absorbance ratios $\left(\mathrm{Abs}_{260 \mathrm{~nm}}-\mathrm{Abs}_{320 \mathrm{~nm}}\right)$ / $\left(\mathrm{Abs}_{280 \mathrm{~nm}}-\mathrm{Abs}_{320 \mathrm{~nm}}\right)$ were calculated and samples with values within the range of 1.6-2.0 were considered as DNA of good quality.

In addition, to verify the integrity and quality of the obtained DNA, a $0.8 \%$ agar gel electrophoresis was performed and a $1 \%$ agar gel electrophoresis after samples digestion with the restriction enzymes EcoRI and BamHI (Promega, USA) for 4 hours, according to the manufacturer's specifications. For both electrophoresis, $8 \mu$ of the undigested or digested DNA $+2 \mu$ l Blue / Orange 6X Loading Dye (Promega, USA) was placed in each well. Phage $\lambda$ DNA (Sigma-Aldrich, USA) was used as the molecular weight marker. Both gels were run at $120 \mathrm{~V} / 1$ hour.

Staining was performed by incubating the gel with $500 \mathrm{~mL}$ of a solution of SYBR® Green I (dilution 1/10000) (Sigma-Aldrich, USA) for 30 minutes in the dark. The gels were visualized with a transilluminator (Vilber-Lourmat, France).

\section{Results and Discussions}

For all genotypes seed germination percentages higher than 95\%, were obtained in the 14-day period (Figure 1). GA3 is capable of promoting germination and causing the rupture of the 
characteristic cyclic dormancy of tobacco seeds, particularly, in those seeds stored for several years (Juan Luis Pérez, Cuba Nicotiana Germplasm personal communication).

With this genomic DNA extraction method can be processed in our laboratory up to 60 samples per day. In addition, the use of the combination homogenizer-EB reduces the duration time of the extraction step to one minute.

The presence of $\mathrm{NaCl}$ in the $\mathrm{EB}$ allows the removal of the polysaccharides and proteins that are bound to the DNA and increases the solubility of these two biomolecules (have a solubility similar to that of DNA) in isopropanol or ethanol, which reduces their co-precipitation with the DNA in the polar solvents $[6,9,12]$. On the other hand, EDTA, a chelating agent, traps divalent cations such as $\mathrm{Mg}^{2+}$ and $\mathrm{Ca}^{2+}$ and inhibits the action of nucleases that require these ions for their enzymatic activity $[13,14]$. SDS detergent is able to dissolve the lipids of cell membranes and thus releasing cytoplasmic and nuclear contents [15]. The DNA extraction step with the P: C: I solution allowed to recover about $400 \mu$ of the aqueous phase and the removal of polysaccharides, lipids, polyphenols and other non-polar compounds from the aqueous phase [16], resulting in clearer and higher quality DNA.

All values of the absorbance ratios were maintained in the range of 1.6-2.0 (Table 1) in compliance with the quality parameters established in Materials and Methods. The DNA concentrations were between $0.73 \mu \mathrm{g} / \mu \mathrm{l}$ for the cultivar Habana-2000 and $1.47 \mu \mathrm{g} / \mu \mathrm{l}$ for the cultivar Criollo. These concentration values are suitable for subsequent uses of DNA in the laboratory in techniques such as PCR or restriction enzyme digestion where quantities as low as $7.5-50 \mathrm{ng}$ or $0.8-1 \mu \mathrm{g} / \mu \mathrm{l}$, respectively, are employed.

It is evident that using the protocol it can be obtained high molecular weight DNA and decreases the presence of nucleic acids of low molecular weight (Figure 2a). Furthermore, a significative smear effect is not observed as a result of a DNA degradation process.

The highest concentration DNA samples isolated, which underwent the enzymatic digestion process with EcoRI and BamHI, were succesfully digested, showing a clear, constant and reproducible banding pattern across all samples and (Figure 2b) demonstrating the efficiency of the method developed in this study.

It is also important to note the influence of the mass of the starting plant material for extraction. Although the expected DNA yield of a small mass samples should be low, the chances that contaminants co-precipitate with the DNA are also low, due to the fact that during the precipitation the concentrations of saturation won't be reached or exceed.

\section{Absorbance ratios and DNA concentrations from tobacco genotypes analyzed in this study}

\begin{tabular}{|c|c|c|c|}
\hline Cultivar name & Tobacco type & $\begin{array}{l}\left(A b S_{260 n m}-A b S_{320 n m}\right) ! \\
\left(A b S_{280 n m}-A b S_{320 n m}\right)^{* *}\end{array}$ & {$[A D N] \mu g / \mu L$} \\
\hline Wz & Flue-cured & 1.65 & 1.17 \\
\hline Habana-2000 & Dark air-cured & 1.83 & 0.73 \\
\hline Criollo-2010 & Dark air-cured & 1.83 & 0.97 \\
\hline Habana-92 & Dark air-cured & 1.91 & 1.45 \\
\hline Corojo-2006 & Dark air-cured & 1.78 & 1.03 \\
\hline Corojo & Dark air-cured & 1.74 & 1.06 \\
\hline Habana 2.1.1 & Dark air-cured & 1.88 & 0.9 \\
\hline Criollo & Dark air-cured & 1.81 & 1.47 \\
\hline Criollo-98 & Dark air-cured & 1.87 & 1.46 \\
\hline Virginia Isogénica & Flue-cured & 1.93 & 1.18 \\
\hline
\end{tabular}

To my knowledge, it is the first reliable and simple method for the isolation of $N$. tabacum seedlings genomic DNA free from certain secondary metabolites like phenols. Since the Department of Genetics and Phytopathology from the Tobacco Research Institute, Cuba began with the interest in isolating large amounts of DNA, we chose phenol/chloroform/isoamy alcohol extractions combined with quick tobacco seed germination to optimize the obtention process of plant material ready for DNA extraction,instead the current available commercial kits. The DNA we obtained showed to be as contaminant -free as DNA isolated with other extraction methods from wild 
species of genus Nicotiana and cultivars of N.tabacum $[17,18]$.

The amounts and classes of secondary metabolites we can found in plants can vary considerably, that is why is unlikely that an ideal contaminant-free nuclear DNA extraction method will ever be developed. However, it is posible that the N. tabacum genomic DNA extraction method presented in this study can be used to isolate nuclear DNA from a variety of other plant species specially the related with Solanaceae family an the genus Nicotiana.

The extraction method of genomic DNA described here will be useful for molecular, population genetics and breeding approaches in N. tabacum.
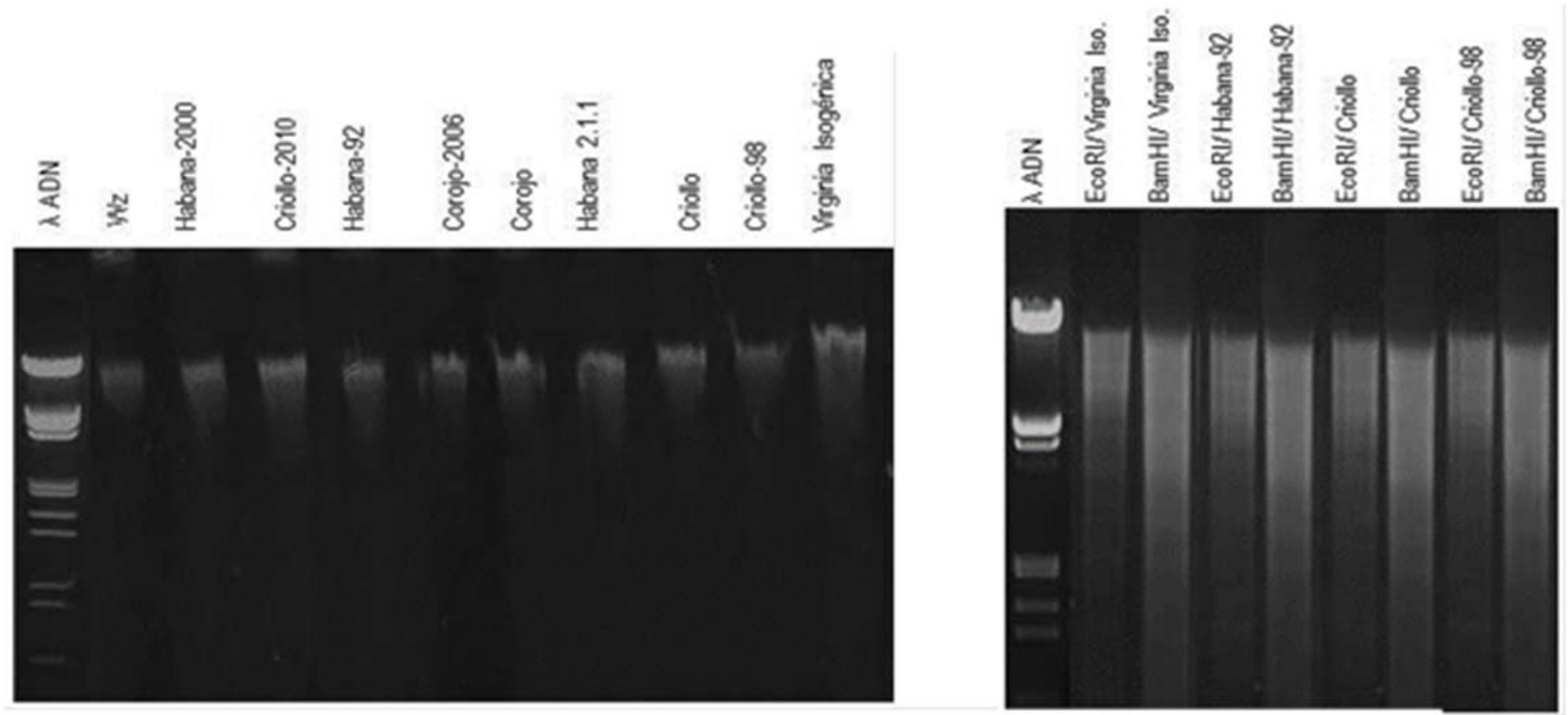

(a)

(b)

Fig. 2. (a) The $0.8 \%$ agarose gel electrophoresis of the different DNA samples obtained by the method proposed in this study; (B) 1\% agarose gel electrophoresis showing the DNA digestion patterns of the genotypes: Virginia Isogenica, Habana-92, Criollo and Criollo-98 cv., with the EcoRI and BamHI restriction enzymes

\section{Conclusions}

The present study described the combination of gibberellic acid for quick tobacco seed germination with an extraction method of genomic DNA from 14-day old tobacco seedlings. The method is fast, economical, simple and does not require the use of hazardous compounds such as liquid nitrogen. A clearer and good quality DNA from different tobacco types was obtained, indicating the suitability of the method for different N.tabacum cultivars. The DNA yield was enough for posterior uses like the digestion with restriction enzymes where a clearer banding pattern demonstrated the DNA integrity obtained.

\section{References}

1. Xin, Z. \& Chen J. (2012). A high throughput DNA extraction method with high yield and quality. Plant Methods, 8 (26), 1-7. doi: 10.1186/1746-4811-8-26

2. Springer, N.M. (2010). Isolation of plant DNA for PCR and genotyping using organic extraction and CTAB. Cold Spring Harbor Protocols, (11), 1228-1229, doi: $10.1101 / p d b . p r o t 5515$.

3. Healey, A., Angelo, F., Tal, C. \& Robert J.H. (2014). Protocol: a simple method for extracting next generation sequencing quality genomic DNA from recalcitrant plant species. Plant Methods, 10 (21), 1-8, doi: 10.1186/1746-4811-10-21.

4. Shabnam, A. \& Saeed A. (2016). An efficient and simple CTAB based method for total genomic DNA isolation from low amounts of aquatic plants with a high level of secondary metabolites. Progress in Biological Sciences, 6 (1), 95-106, doi: 10.1186/2193-1801-2-669.

5. Devi, D.K., Kshetrimayum, P., Nandeibam, S.S. \& Huidrom S.D. (2013). An efficient protocol for total DNA extraction from the members of order Zingiberales-suitable for diverse PCR based downstream applications. SpringerPlus, 2 (669), 1-9, doi: 10.1186/2193-1801-2-669.

6. Swati, R., Geeta, J.D., Annapurna, A.N., Arunkumar, N. \& Karaba N. (2016). Standardization of DNA Extraction Method from Mature Dried Leaves and ISSR-PCR Conditions for Melia dubia Cav.--A Fast Growing Multipurpose Tree Species. American Journal of Plant Science, 7, 437-445,

7. Minas, K., McEwan, N.R., Newbold, C.J. \& Scott K.P. (2011). Optimization of a high-throughput CTABbased protocol for the extraction of qPCR-grade DNA from rumen fluid, plant and bacterial pure cultures. FEMS Microbiol. Lett. 325, 162-169, doi: 10.1111/j.15746968.2011.02424.x.. 
8. Handayani, F., Wulandari, R.A. \& Murti R.H. (2016). Genomic DNA extraction method from mature leaf of lai (Durio kutejensis Becc.). AGRIVITA, 38 (1), 73-79.

9. Amani, A-L. \& Gamal O. (2017). Comparison of three genomic DNA extraction methods to obtain high DNA quality from maize. Plant Methods, 13 (1), 1-9, doi: 10.1186/s13007-016-0152-4.

10. Edwards, K., Johnstone, C. \& Thompson C. (1991). A simple and rapid method for the preparation of plant genomic DNA for PCR analysis. Nucl. Acid Res. 19 (6), 1349.

11. Interpretation of Nucleic Acid 260/280 Ratios. T123Technical Bulletin NanoDrop Lite, 2012, Thermo Scientific; EE.UU

12. Tamari, F., Hinkley, C.S. \& Ramprashad N. (2013). A Comparison of DNA Extraction Methods using Petunia hybrida Tissues. J Biomol Tech. 24 (3), 113118, doi: 10.7171/jbt.13-2403-001.

13. Amjad, M.N., Faheem, S.B., Hafiz, M.R., Bao, L., Fahima, A., Seung, H.Y. \& Gyuhwa C. (2016). Development of a Competent and Trouble Free DNA Isolation Protocol for Downstream Genetic Analyses in Glycine Species. Turkish Journal of Agriculture - Food Science and Technology, 4 (8), 700-705, doi.org/10.24925/turjaf.v4i8.700-705.788
14. Trzewik, A., Nowak, K.J. \& Orlikowska T. (2016). A simple method for extracting DNA from rhododendron plants infected with Phytophthora spp. for use in PCR. J.Plant Protection Res. 56 (1), 104-109, doi.org/10.1515/jppr-2016-0014.

15. Sikaa, K.C., Kefela, T., Adoukonou-Sagbadja, H., Ahoton, L., Saidou, A., Baba-Moussa, L., Baptiste, L.J., Kotconi, S.O. \& Gachomo E.W. (2015). A simple and efficient genomic DNA extraction protocol for large scale genetic analyses of plant biological systems. Plant Gene, 1, 43-45, https://doi.org/10.1016/j.plgene.2015.03.001.

16. Ahmad, J., Ibrahim, M.M. Baig, M.A., Ali, A.A. \& Qureshi M.I. (2016). Standardization of DNA extraction from invasive alien weed Parthenium hysterophorus. African Journal of Biotechnology, 15 (22), 1035-1040, doi: 10.5897/AJB2016.15232.

17. Amani, J., Roohallah, K., Abbasi, A.R. \& Salmanian, A.H. (2011). A simple and rapid leaf genomic DNA extraction method for polymerase chain reaction analysis. Iranian Journal of Biotechnology, 9 (1), 69-71.

18. Li, Y., Zhao, H., Yan, X., Li, M., Chen, P. \& Zhang, S. (2017). A universal method for direct PCR amplification of plan tissues. Analytical Methods, 9, 1800-1805, doi: 10.1039/C6AY03156K. 